\title{
The right to education for young people excluded from mainstream in a divided society

\author{
PATRICIA O'LYNN ${ }^{1}$
}

Queen's University Belfast

\begin{abstract}
This paper offers a rights-based analysis of the equity of educational experience allocated to young people excluded from school in Northern Ireland. Using Tomaševski's '4As scheme' as a conceptual guide, the availability, accessibility, acceptability and adaptability of alternative education provision is examined. The article begins with a brief overview of the contextual landscape within which the sector operates, alluding to the definitional and procedural difficulties that have bindered the delivery of equitable alternative education services to date, before an examination of the current legal architecture within which the right to education may be given further realisation is detailed. The latter part of the article considers the extent to which the organisation, management and delivery of the EOTAS sector is rights-compliant, before concluding that the right to education, as it stands under domestic and international law, does not extend far enough to ensure and protect the educational entitlements of children excluded from school.
\end{abstract}

\section{Introduction}

$\mathrm{E}$ merging from 30 years of conflict, Northern Ireland is an interesting jurisdiction in which to study children's enjoyment of the right to education. ${ }^{2}$ Human rights, in general, have had a significant impact in facilitating the transition from conflict stemming from the Belfast or 'Good Friday' Agreement of 1998. ${ }^{3}$ This is evidenced by the establishment of a Human Rights Commission, ${ }^{4}$ an Equality Commission ${ }^{5}$ and a Commissioner for Children and Young People. ${ }^{6}$ In post-conflict societies, education systems are at the heart of reform and reinstatement of peace. ${ }^{7}$ Article 29 of the UN

1 School of Education.

2 Laura Lundy et al, The UN Convention on the Rights of the Child: A Study of Legal Implementation in 12 Countries (UNICEF 2013) 126.

3 Colin Harvey (ed), Human Rights, Equality and Democratic Renewal in Northern Ireland (Hart 2001).

4 Northern Ireland Act 1998, s 68(1); Laura Lundy et al, 'Education Reform in Northern Ireland - A Human Rights Review' (Northern Ireland Human Rights Commission 2012) 11.

5 Northern Ireland Act 1998, s 73(1); 'Draft Statement on Key Inequalities in Northern Ireland' (Equality Commission for Northern Ireland 2015) < hwww.equalityni.org/ECNI/media/ECNI/Publications/ Delivering\%20Equality/Education-KeyInequalities_DraftStatement.pdf $>$.

6 Commissioner for Children and Young People Order (NI) 2003; U Kilkelly et al, 'Children's Rights in Northern Ireland' (NICCY 2004) < http://dera.ioe.ac.uk/9165/1/22323\%20Final.pdf>.

7 Laura Lundy, 'Mainstreaming Children's Rights In, To and Through Education in a Society Emerging from Conflict' (2006) 14 International Journal of Children's Rights 339. 
Convention on the Rights of the Child (UNCRC) states that education 'shall promote understanding, tolerance and friendship among all nations, racial or religious groups and shall further the activities of the United Nations for the maintenance of peace'. 8 Teaching children and young people to respect and value difference whilst providing the skills to resolve conflict peacefully are core aims of the right to education that provide an opportunity for the reduction and cessation of violence in the future. ${ }^{9}$ To that end, it should also be noted that education is not only a human right in itself with intrinsic value, but also acts as an 'indispensable means of realising and promoting other human rights ${ }^{\text {'10 }}$ and basic democratic principles for contribution to wider society. As such, the right to education may be regarded as a 'multiplier of rights', ${ }^{11}$ empowering individuals with the skills, capacity and ability necessary to realise, invoke and enjoy other human rights ${ }^{12}$ when it is secured and likewise 'undermining that potential when it is denied'. ${ }^{13}$ Despite the existence of this right, exclusion from school can still be imposed on those who display disruptive behaviours. ${ }^{14}$

Northern Ireland remains a deeply divided society wherein the education system is characterised by religious segregation with attendant widespread inequalities. ${ }^{15}$ In addition to the negative effects of a polarised system, which employs processes of academic selection of pupils at age 11,16 a further division opens up if children who are subject to school exclusion are taken into consideration. ${ }^{17}$ The NI Education and Training Inspectorate (ETI) consistently raises concerns over the lack of equitable provision for excluded children in alternative placements, ${ }^{18}$ which demonstrates a deep disjuncture between the aspirations of international human rights law, domestic government and the educational experiences of children in Northern Ireland. There tends to be a level of confusion about what exactly school exclusion means. This article employs a wide interpretation of the term, recognising that it does not simply mean formal, permanent expulsion, but also includes temporary exclusions as well as those which are informal in nature and illegal in practice. Consideration will also be given to

8 UNCRC 1989, Article 29.

9 UN Committee on the Rights of the Child, General Comment No 1 (2001), Article 29 (1): The Aims of Education, 17 April 2001, CRC/GC/2001/1, para 16.

10 CESCR, General Comment No 13: The Right to Education (Article 13 of the Covenant), 8 December 1999 , E/C12/1999/10, para 1.

11 Katarina Tomaševski, Annual Report of the Special Rapporteur on the Right to Education, 11 January 2001, $\mathrm{E} / \mathrm{CN} 4 / 2001 / 52$.

12 Manisuli Ssenyonjo, Economic Social and Cultural Rights in International Law (OUP 2009) 356.

13 Laura Lundy (n 7) 339.

14 Sheila Riddell and Gillean McCluskey, 'Policy and Provision for Children with Social, Emotional and Behavioural Difficulties in Scotland: Intersections of Gender and Deprivation' in Ted Cole, Harry Daniels and John Visser (eds), The Routledge International Companion to Emotional and Behavioural Difficulties (Routledge 2012) 57-67.

15 Alexandra Barr, Rosemary Kilpatrick and Laura Lundy, 'School Exclusions: Lessons from Northern Ireland' (2000) 12 Education and the Law 165, 166.

16 Laura Lundy et al (n 4) 11.

17 A set of common procedures to deal with school exclusion exists, however there is little agreement over the grounds for exclusion. This is attributable to the fact that schooling in Northern Ireland is religiously segregated, meaning that the rationale for exclusion across the four main 'school types' (i.e. controlled, maintained, voluntary and grant-maintained integrated) varies greatly. In addition, once outside the mainstream system, options for alternative provision in line with religious affiliation will be greatly diminished and may act as a further barrier to re-engagement with learning. For further information, see Peter Bryson, 'Alternative Education, Equity and Compromise: Dilemma for Practice Development' (2010) 16 Child Care in Practice 347, 348; Barr et al (n 15).

18 The Chief Inspector's Report 2010-2012 (ETI 2012) 16, 66; The Chief Inspector's Report 2012-2014 (ETI 2014$) 69$. 
in-school exclusions implemented by isolating the pupil from their peers within the school environment, which are legally permissible yet offend human rights principles.

Exclusion from school is extremely costly to the young person, their family and society as a whole. ${ }^{19}$ Research has found that those excluded from school are more likely to have additional or special needs and to live in families who are affected by poverty, ill health or trauma; ${ }^{20}$ are 90 times more likely to become homeless; ${ }^{21}$ are at an increased risk of misusing drugs; ${ }^{22}$ and have a higher probability of being incarcerated as a youth. ${ }^{23}$ These individuals are not only excluded from school but are also at risk of exclusion from society in its entirety and, it has been argued, form part of an ever increasing 'underclass', ${ }^{24}$ living life on the margins of society. ${ }^{25}$ The Department of Education in Northern Ireland (DENI) has recorded a year-on-year reduction in the rate of permanent school exclusions. ${ }^{26}$ However, there is a growing body of international research which suggests current figures may not be entirely accurate. ${ }^{27}$ Substantial rises in the use of 'temporary exclusions' 28 are concerning in the light of international findings suggesting that implementing a suspension may be seen as a more favourable option in terms of preserving the integrity of a school's reputation, as opposed to the blemish of a formal expulsion, yet may have more detrimental effects on the pupil.

This is construed as a disadvantage by schools in the current neoliberal market characterised by extreme competitiveness. ${ }^{29}$ Likewise, the practice of 'isolation' as an inschool form of punishment ${ }^{30}$ has the potential to exclude young people from the curriculum as well as the social aspects of mainstream schooling. Such in-school

19 For an analysis of such costs, see: Jane Evans, Not Present and Not Correct: Understanding and Preventing School Exclusions (Barnardo's 2010); Carl Parsons, Strategic Alternatives to Exclusion from School: Revised and Updated Edition (Trentham Books 2009); Pat Thomson and Jodie Pennacchia, What's the Alternative? Effective Support for Young People Disengaging from Mainstream Education (Prince's Trust 2013); Eamonn Gallagher, 'The Second Chance School' (2010) 15 International Journal of Inclusive Education 445.

20 Kilpatrick et al (n 25) 6.

21 Gerry German, 'Exclusion Isn't the Answer' (2003) Young People Now 7-13.

22 Laura Duncan and Patrick McCrystal, 'School Exclusion and Adolescent Drug Use in Northern Ireland: A Problem Being Addressed?’ (2002) 8 Child Care in Practice 176.

23 Antonino Merlo and Kenneth I Wolpin, 'The Transition from School to Jail: Youth Crime and High School Completion among Black Males’ (2015) 79 European Economic Review 234.

24 Robert MacDonald (ed), Youth, The Underclass and Social Exclusion (Routledge 1997).

25 Rosemary Kilpatrick et al, 'Out of the Box - Alternative Education Provision (AEP) in Northern Ireland' (Department of Education 2007).

26 DENI record of yearly pupil expulsions and suspensions, available at <www.deni.gov.uk/articles/pupilsuspensions-and-expulsions>.

27 Roger Smith, No Lessons Learnt: A Survey of School Exclusions (Children's Society 1998); Social Exclusion Unit, Truancy and Social Exclusion (1998); Social Exclusion Unit, Preventing Social Exclusion (2001); Sheila Macrae, Meg Maguire and Linda Milbourne, 'Social Exclusion: Exclusion from School' (2003) 2 International Journal of Inclusive Education 89; Anne Pirie and Gale Macleod, 'Locked Out: Researching Destinations and Outcomes for Pupils Excluded from Special Schools and Pupil Referral Units' (2009) 14 Emotional and Behavioural Difficulties 185; Brenda Parkes, 'Exclusion of Pupils from School in the UK' (2012) 8 Equal Rights Review 113.

28 DENI (n 26).

29 Colin Coulter, 'The Absence of Class Politics in Northern Ireland' (1999) 69 Capital and Class 77; Stephen J Ball, 'The Teacher's Soul and the Terrors of Performativity' (2003) 18 Journal of Education Policy 215; Stephen J Ball (ed), The Routledge Falmer Reader in Sociology of Education (Routledge Falmer 2004); Stephen J Ball, Education Policy and Social Class: The Selected Works of Stephen J Ball (Routledge 2006); Stephen J Ball, Global Education Inc: New Policy Networks and the Neo-Liberal Imaginary (Routledge 2012).

30 Laura Lundy, Education: Law, Policy and Practice in Northern Ireland (SLS 2000) 218. 
exclusions'31 can lead to disengagement which goes unrecognised, unquantified and unaddressed.

Lundy and Byrne, 32 in discussing barriers to effective government delivery of children's policy and children's rights, identified the 'delay in policy development and implementation; lack of coordination and joined up government; insufficient data; limited engagement with children and young people; and limited commitment to children's rights' 33 as inhibitors to the full realisation of child rights in Northern Ireland. By applying these benchmarks to the Education Otherwise than at School (EOTAS) sector, it would appear that the educational experiences afforded to children outside the mainstream system may, in some instances, fall short of the expected standards. Prior to the devolution of powers to the Northern Ireland Assembly, which took effect in 1999, ${ }^{34}$ Northern Ireland's education system was constrained by 'wider constitutional questions and ongoing power relay between Direct Rule by Westminster and devolved government'. 35 However, since devolution, the trend towards eradicating educational inequalities has dominated the political and policy spheres in Northern Ireland. ${ }^{36}$ This has also been characterised by a deep disjuncture between government aspirations, policy aims and the lived experiences of intended beneficiaries.

As part of a 'School Improvement Programme', DENI published its policy position on 'Promoting and Sustaining Behaviour: A Discipline Strategy for Schools' in 1999. ${ }^{37}$ Its overarching aim was that of maintaining pupils in mainstream schooling and creating fully inclusive schools, envisaging the development of an effective and co-ordinated support system which would equip schools to manage all but the most difficult of pupils within their resources. ${ }^{38}$ Whilst the review set out that the best place for children and young people to be educated is in the mainstream system, it also recognised that for 'a small minority of pupils ... all such in-school measures may not prove effective' and that they may require 'a period of specialised provision geared to breaking the cycle of underachievement, disaffection and disruption'. ${ }^{39}$ Whilst the strategy recognised the need for alternatives to mainstream placements, it was also critical of the sector. It noted that a more consistent approach needed to be taken in ensuring the quality of out-of-school provision as well as effective access to such services, ${ }^{40}$ the main objective of which was said to be:

That the needs of pupils with the same behavioural problems, in similar circumstances, in different areas of Northern Ireland should be addressed through similar levels of support, including (where withdrawal is considered appropriate) access to similar facilities. ${ }^{41}$

31 Alan Gordon, 'School Exclusions in England: Children's Voices and Adult Solutions?' (2001) 27 Educational Studies 69.

32 Bronagh Byrne and Laura Lundy, 'Reconciling Children's Policy and Children's Rights: Barriers to Effective Government Delivery' (2015) 29 Children and Society 266.

33 Ibid 5.

34 Northern Ireland Act 1998.

35 Byrne and Lundy (n 32) 4.

36 Ibid.

37 'Promoting and Sustaining Good Behaviour: A Discipline Strategy for Schools' (DENI 1999).

38 Ibid para 3.13 .

39 Ibid para 4.2.

40 Ibid para 4.7.

41 Ibid. 
Since then, a string of further policy developments have followed with the aim of identifying early those pupils who are struggling to learn ${ }^{42}$ by assessing needs and providing adequate intervention ${ }^{43}$ that promotes inclusion ${ }^{44}$ and by developing an ethos of reflection and rigorous self-evaluation ${ }^{45}$ in schools. This has been matched by the development and implementation of a Revised Curriculum and Entitlement Framework, ${ }^{46}$ which sought to ensure greater choice and flexibility of learning using a broad and balanced curriculum designed to suit the needs of pupils. ${ }^{47}$ The cumulative effect of these education policies was intended to have a positive impact on the ability of schools to meet the needs of all pupils, especially those becoming school-distant, at risk of marginalisation, disaffection and disengagement. However, whilst some positive strides have been made in this regard, ${ }^{48}$ there has remained a dearth of joined-up, focused strategic direction and guidance specifically governing the finance, operation and delivery of equitable EOTAS services since that period.

Most recently, the five legacy Education and Library Boards which governed the education system amalgamated to form one single Education Authority. ${ }^{49}$ Such a change represents an ideal opportunity to standardise and revamp educational practice for all young people in Northern Ireland but not least, for the purposes of this article, children and young people suffering the effects of exclusion. Such opportunity has been evidenced in newly publicised DENI guidance on the use of EOTAS services. ${ }^{50}$ This has established the baseline and common features for all EOTAS settings by stipulating the minimum requirements of operation in an alternative education setting. ${ }^{51}$ The new guidance has been issued in preparation for a tendering and procurement exercise whereby community alternative education services will be consolidated to one provider, successful in the tendering competition, from which the Authority 'may' purchase placements. ${ }^{52}$

Although such developments may be viewed in a positive light, as there are good arguments in favour of standardising EOTAS provision across the North, current procedures for assessing the needs of intended beneficiaries are lacking. Taylor has highlighted that alternative provision is a 'complex service to plan, deliver and get right', ${ }^{53}$ which goes some way toward explaining the lacklustre assessments which are in use. When thinking about change, efforts must not only be directed towards those pupils currently in direct receipt of EOTAS provision, they must also challenge the disjuncture that currently exists between policy and practice with the aim of developing an overarching strategic plan that ensures the implementation of consistent and effective EOTAS services meeting the educational entitlements of all children in alternative

42 'Every School a Good School - The Way Forward for Special Educational Needs and Inclusion' (DENI 2009).

43 Ibid

44 'Pastoral Care in Schools: Promoting Positive Behaviour' (DENI 2001).

45 'Every School a Good School' (n 42); 'Together Towards Improvement: A Process for Self-Evaluation: Post Primary' (ETI 2003).

46 Education (NI) Order 1998.

47 'Section 75 Audit of Inequalities and Action Plan' (DENI 2012): <www.deni.gov.uk/de1_12_7205_final_ published_version_audit_of_inequalities_action_plan_june_2012.pdf $>$.

48 'Report of an Evaluation of Pupil Behaviour in Schools and Other Educational Settings' (ETI 2010).

49 Education Act (NI) 2014.

50 'Guidance on Education Other Than at School' (DENI 2014): <www.deni.gov.uk/sites/default/ files/publications/de/pdf-format-2014-eotas-guidance-document.pdf>.

51 Ibid para 1.1.

52 Ibid.

53 Charlie Taylor, 'Improving Alternative Provision' (Department for Education 2012) <www.gov.uk/ government/publications/improving-alternative-provision>. 
education, commensurate with the aspirations of the EOTAS guidance. Taylor explains that alternatives to mainstream school are found to be most effective when positioned clearly as an integral part of the wider local education system that is well organised, well resourced and contains responsive interventions. ${ }^{54}$ Until further operational policy with corresponding finance and support is delivered by the Northern Ireland government, the requisite availability, accessibility, acceptability and adaptability ${ }^{55}$ requirements of EOTAS services will remain moot points.

\section{Limits on the right to education in Northern Ireland}

Within the transitional context of Northern Ireland, human rights discourse plays a prominent role. ${ }^{56}$ As a result of 30 years of violent conflict and corresponding allegations of inequality, there is a readiness to deploy human rights arguments in order to promote change. ${ }^{57}$ Such readiness coupled with the entrenchment of 'rights-talk' 58 throughout the jurisdiction means that 'critical questions can be legitimately raised about the transformative impact of such a mainstream practice. 59 Considering that schools in Northern Ireland are largely religiously, academically and to some extent socioeconomically segregated, this has provided a 'public outlet' 60 where rights infringements and corresponding claims may arise frequently. ${ }^{61}$ However, the complex constitutional context of the UK is such that there are considerable limitations on rights-based claims regarding education ${ }^{62}$ and the ability of such claims to make a practical difference to young people excluded from school in accessing quality EOTAS services in Northern Ireland. The impact of the rights regime in Northern Ireland is mitigated by the UK's dualist approach to international treaties, whereby the state may have ratified international human rights instruments but they may have little domestic impact if not incorporated into domestic law. ${ }^{63}$ This is further complicated by the UK's regional relationship to the EU, to date, wherein the Charter of Fundamental Rights, Article 14, ${ }^{64}$ offers guarantees only if matters of EU law are engaged.

54 Ibid para 4.

55 Tomaševski (n 11).

56 Catherine O'Rourke, 'Rights-Based Social Mobilisations: Rights Discourses in Transition - Examining Human Rights as a Tool for the Advancement of Women in Transitional Northern Ireland' (presented at Centre for the Study of Human Rights, LSE, 20 March 2007): <www.lse.ac.uk/humanRights/aboutUs/ articlesAndTranscripts/Conference07_ORourke.pdf>.

57 Lundy (n 7) 340.

58 Colin Harvey, 'Bringing Humanity Home: A Transformational Human Rights Culture for Northern Ireland?' in Anne-Marie McAlinden and Clare Dwyer (eds), Criminal Justice in Transition: The Northern Ireland Context (Hart 2015) 48 .

59 Ibid.

60 Lundy (n 7) 340.

61 Ibid.

62 Harvey (n 58).

63 Ibid 51.

64 Article 14 of the Charter of Fundamental Rights reads: ' 1 . Everyone has the right to education and to have access to vocational and continuing training 2 . This right includes the possibility to receive free compulsory education 3. The freedom to found educational establishments with due respect for democratic principles and the right of parents to ensure the education and teaching of their children in conformity with their religious, philosophical and pedagogical convictions shall be respected, in accordance with the national laws governing the exercise of such freedom and right'. 
Internationally, the right to education has been included in various agreements and declarations. ${ }^{65}$ Article 26 of the Universal Declaration of Human Rights (UDHR) formed the basis providing for further guarantees of the right to education in later instruments. Conformity with the UDHR requires states to ensure positive obligations are fulfilled via the implementation of three basic characteristics of the right to education that consist of the right to receive an education; a guarantee for the exercise of parental rights in educational issues; and all with reference being made to the aims of education. ${ }^{66}$ This was reaffirmed by signatories to the International Covenant on Economic, Social and Cultural Rights (ICESCR). Here the right to education finds its most comprehensive guarantee in international human rights law. ${ }^{67}$ The ICESCR binds ratifying state parties to realise the right to education for all, regardless of age, language, social or ethnic origin, by ensuring it is made 'generally available and accessible to all'. ${ }^{68}$ Article 13(1) lists the aims education should achieve in society, while Article 13(2) enumerates the steps states must take to ensure that full realisation of the right to education is achieved in a nondiscriminatory way. ${ }^{69}$

Furthermore, the UNCRC sets out the civil, political, economic, social, health and cultural rights of children, which have the potential to be applied in the domain of education. ${ }^{70}$ Such rights are commonly categorised as rights to, in and through education. ${ }^{71}$ In general terms, the right to education can be taken to mean the child's right of equal access to education. The right in education makes reference to the right to be treated with dignity, respect and equality while at school, whilst the right through education refers to the content and aims of education young people are entitled to receive. Article 28 of the UNCRC explicitly protects 'the right of the child to education, and with a view to achieving this right progressively and on the basis of equality of opportunity'. Article 29 is concerned with the aims of education, or rights through education. Both Articles should be read together as they are interlinked in that 'the right to receive education does not only guarantee access to education but also implies that the aims of education must be achieved'. ${ }^{72}$

This complex plethora of incorporated and unincorporated legal protections agreed through international law means that the broad spread of standards outlined above may not necessarily have much impact on domestic practice. This is not to say that the standards agreed to in such international agreements are entirely idealistic, aspirational or irrelevant. As Harvey explains:

65 UDHR, Article 26; ICECSR, Articles 13-14; UNCRC, Articles 28-9; Convention Against Discrimination in Education, Article 5(1); World Declaration on Education for All; ECHR Protocol 1, Article 2; Protocol of San Salvador, Article 13; African Charter on Human and Peoples' Rights, Article 17. For discussion on the protection of the right to education by regional legal instruments, see: Klaus Dieter Beiter, The Protection of the Right to Education by International Law: Including a Systematic Analysis of Article 13 of the International Covenant on Economic, Social and Cultural Rights (Martinus Nijhoff 2006) 155-224.

66 Fons Coomans, 'Education and Work' in Daniel Moecki et al (eds), International Human Rights Law 2nd edn (OUP 2013) 239.

67 CESCR, General Comment No 13 (n 10) para 2.

68 Ibid.

69 Ibid.

70 Lesley Emerson and Laura Lundy, 'Education Rights in a Society Emerging from Conflict' in B B Swadener et al (eds), Children's Rights and Education: International Perspectives (Peter Lang 2013) 19.

71 'Children's Rights: Rhetoric or Reality: A Review of Children's Rights in Northern Ireland' (NICCY 2009).

72 Mieke Verheyde, A Commentary on the United Nations Convention on the Rights of the Child: Article 28, the Right to Education (Martinus Nijhoff 2006) 1. 
... [i] $\mathrm{n}$ addition to the formal way they enter courtrooms, international norms continue to be regularly used in arguments and debates that flow from civil society. The fact that international human rights standards are not incorporated into domestic law does not for example mean they cannot be taught and awareness of their existence raised or that they should not be used by anyone who wishes to offer a critique informed by external benchmarks. ${ }^{73}$

Thus, a 'bare description of the legal architecture does not capture the fluidity of current rights discourse' in Northern Ireland. ${ }^{74}$ Child rights in particular are regularly used in societies emerging from conflict as a 'set of benchmarks for what is necessary to redress the social, psychological and physical impacts of violence' ${ }^{75}$ Likewise, there are national and international interests in securing child rights in general, but more so in realising the aims of education stipulated by Article 29 of the UNCRC. ${ }^{76}$ On this point, Lundy elaborates that 'there is a compelling public interest in guaranteeing children's right to education since the social and economic well-being of society depends on having a welleducated citizenry and one that respects democratic values, including human rights'. ${ }^{77}$

With regards to justiciable international education rights in Northern Ireland, Article 2 of the First Protocol (A2P1) to the European Convention on Human Rights (ECHR), which was incorporated into UK law by the Human Rights Act 1998, guarantees that no person shall be denied the right to education. However, as Van Bueren highlights, the potential of positive obligations placed on state parties is 'significantly limited by the first sentence and its phraseology in the negative'. ${ }^{78}$ That being said, the European Court of Human Rights (ECtHR) has not accepted that the duty is wholly negative, saying that it 'cannot be concluded that the State has no positive obligation to ensure respect for such a right as is protected by Article 2 of the Protocol'. ${ }^{79}$ However the negative phraseology has certainly limited the extent of any obligation to expend significant resources on the right to education, which has created the potential for substantial variations in the quality of education offered among member states. ${ }^{80}$ The negative formulation of the first sentence of A2P1 confirms that state parties did not recognise the right to education as one that requires them to establish schools at their own expense or to subsidise education at any particular level or type, ${ }^{81}$ but rather that state parties must guarantee persons within their jurisdiction the right in principle to avail themselves of the means of instruction existing at a given time. ${ }^{82}$

In recent years there has been a change in Strasbourg's approach towards A2P1, which has aided challenges based on the ECHR compatibility of individual suspension and expulsion decisions. ${ }^{83}$ This has developed in line with Strasbourg's approach to the ECHR as a 'living instrument', which now paves the way for challenges to be made based

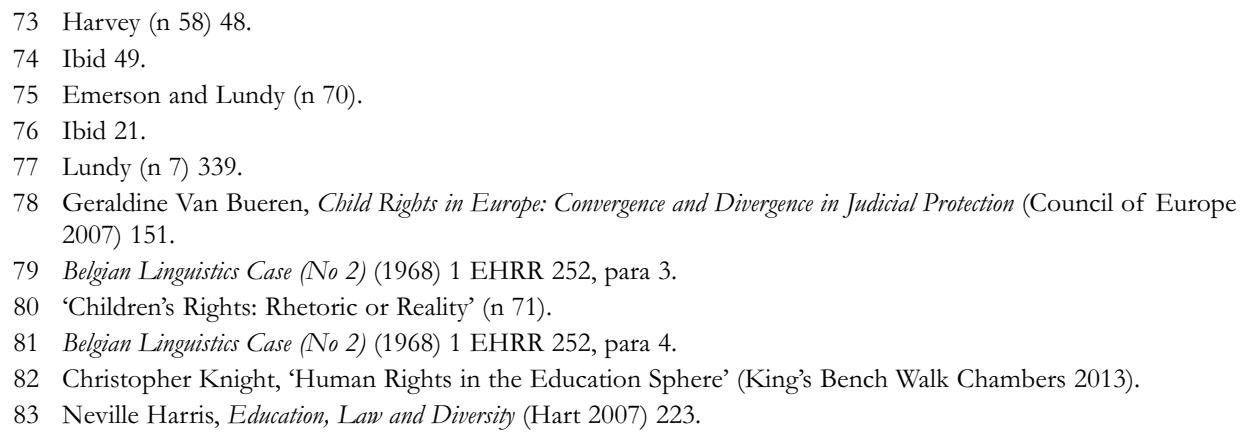


on the test of the quality of provision in alternative education services. ${ }^{84}$ However, such developments appear not to have been reflected in UK case law to date, ${ }^{85}$ where there is little evidence to suggest that domestic courts are willing to utilise the available framework in aid of the educational entitlements of school excludees. This point will be revisited and developed further below.

With regards to young people excluded from school in Northern Ireland, their right to education is written into domestic legislation via article 86(1) of the Education (NI) Order 1998. This states that arrangements must be made:

... for the provision of suitable education at school or otherwise than at school for those children of compulsory school age who by reason of illness, expulsion or suspension from school or otherwise, may not for any period receive suitable education unless such arrangements are made for them.

Prior to the creation of a singular Education Authority, education was organised and administered for excluded pupils across Northern Ireland via the direction of five Education and Library Boards (ELBs) broken down by geographic region. ${ }^{86}$ The legacy ELBs maintained statutory responsibility for ensuring children outside of the mainstream system had their right to education met via the provision of alternative educational services. ${ }^{87}$ The availability, accessibility, quality and type of alternative provision offered differed in accordance with the location in which the pupil lived. ${ }^{88}$ The aim of amalgamating the ELBs was to ensure parity of educational opportunity and experience afforded to all young people across the North, not least those in need of EOTAS services. ${ }^{89}$ However, this has been slow to progress. The Education Authority, on its website, makes the disclaimer that 'services continue to be managed and delivered according to the five geographic areas defined by the former Education and Library Boards'. ${ }^{90}$ Thus, the inequities characteristic of operating five separate ELBs continue to exist in the guise of an Education Authority, where the negative impact which was meant to be eradicated remains tangible.

The aim of this article is to provide evidence in support of the argument that the right to education by virtue of domestic and international law in Northern Ireland does not extend far enough to ensure and protect educational entitlements for children and young people excluded from school. The article does not purport to offer a one-stop solution to all of the issues and inequalities inherent in the processes described above. It will, however, suggest a starting point whereby the right to education can be better guaranteed when non-child-specific barriers to the full realisation of education rights are addressed. For example, it is recommended that adopting a child rights-compliant approach to policy

84 George Letsas, 'The ECHR as a Living Instrument: Its Meaning and Legitimacy' in Andreas Føllesdal, Bergit Peters and Geir Ulfstein (eds), Constituting Europe: The European Court of Human Rights in a National, European and Global Context (CUP 2013) 106-41.

85 Ali v Head Teacher and Governors of Lord Grey School [2006] UKHL 14, [2006] 2 AC 363; Re JR17's Application [2010] UKSC 27, [2010] NI 105.

86 These were the Belfast, North Eastern, South Eastern, Southern and Western Education and Library Boards.

87 Education (NI) Order 1998, article 86.

88 For a further discussion on the differential standard of quality in EOTAS provision, see 'Education Otherwise Than At School Inspection Reports' (ETI) <www.etini.gov.uk/index/inspection-reports/inspection-reportseducation-other-than-at-school-provision.htm>.

89 'Pastoral Care in Schools' ( $\mathrm{n}$ 44).

90 'Organisational Structure' (Education Authority of Northern Ireland): <www.eani.org.uk/aboutus/organisational-structure $>$. 
development and implementation requires adequate processes to be in place to ensure accurate data collection and disaggregation. ${ }^{91}$ This would allow a full statistical picture to be created of those pupils outside the mainstream system and thereby accentuate the potential of successful and effective policy interventions to be planned and delivered with children and young people as their main focus. ${ }^{92}$ Such figures may not currently be available in a manner which makes effective oversight and management possible. This makes it difficult to enable meaningful improvements which can be implemented and monitored in a way that ensures positive changes for all students, their education and future life chances.

As a preliminary step towards implementing such measures, the focus of this article is on providing an account of EOTAS services available across the North. The overarching aim is to present an assessment of the extent to which educational entitlements are realised via measurements of availability, accessibility, acceptability and adaptability ${ }^{93}$ across EOTAS provision. Identifying and recording current EOTAS operations may act as a valuable mapping exercise to which reference can be made in the forthcoming review of Departmental EOTAS Guidance, due to take place in 2017. The purpose of this effort is not to cast shame or blame on current procedures, practices or decision-makers, but rather to shine light on potential inequalities and offer solutions at a time when the opportunity to rectify issues and implement exemplary provision for all is conceivable.

In recognition of the asymmetrical nature of legal standards on the right to education as discussed above, this assessment employs an analytical framework that groups government obligations that should be adhered to in the pursuit of securing equitable, effective and child-centred educational entitlements for all. Building on the work of Tomaševski, ${ }^{94}$ whose '4As scheme' provides a useful aspirational framework on the right to education, attention will be given to four categorised obligations which will be enumerated with reference to soft law enactments of the CESCR and the UN Committee on the Rights of the Child. Comparisons with other instruments of law, including case law from the UK and jurisprudence from the ECtHR, will be used to illustrate and expand upon the desired normative content of the right to education for school excludees in Northern Ireland. At a general level, the UN Committee on the Rights of the Child argues that 'children do not lose their human rights by virtue of passing through the school gates'. 95 This provision contends that children who prematurely exit the school gates by formal direction or voluntary choice should also be afforded their rights regardless of prior behaviour in school, socio-economic background or complex, individual need. School exclusion simply 'does not equate to the abdication of the responsibility of educational authorities to ensure that the learning needs and aspirations of . . . young people are met'. ${ }^{96}$ Young people who find themselves excluded from the mainstream are no exception to the protective elements of human rights law. Indeed, it is

91 Byrne and Lundy (n 32) 268.

92 Pat Thomson and Lisa Russell, 'Data, Data Everywhere - But Not All the Numbers that Count? Mapping Alternative Provisions for Students Excluded from School' (2009) 13 International Journal of Inclusive Education 423.

93 Katarina Tomaševski, Right to Education Primers No 3: Human Rights Obligations: Making Education Available, Accessible, Acceptable and Adaptable (Novum Grafiska 2001).

94 Ibid.

95 UN Committee on the Rights of the Child, General Comment No 1 (2001), Article 29(1): The Aims of Education, 17 April 2001, CRC/GC/2001/1, 3.

96 Thomson and Russell (n 92) 426. 
argued here that their rights should be subject to greater legal fortification. In the words of Harvey, if human rights law is not making a difference for those who require the protections most, what other purposes is it serving?? 97

\section{Availability}

Part of the difficulty inherent in ensuring all pupils are afforded equality of access to EOTAS services stems from the state obligation to make education for children excluded from school available. ${ }^{98}$ The state has a positive obligation to make education available by setting up and maintaining an education system. ${ }^{99}$ This basic requirement can be defined as the right to receive an education or the social dimension of the right to education. ${ }^{100}$ Article 28 of the UNCRC also imposes an obligation on the state to make education available and accessible at secondary school level. ${ }^{101}$ Article 13(2) of the ICESR defines the stages of development for a system of schools at all levels and establishes a duty on states to provide different levels and forms of education. ${ }^{102}$ Verheyde argues that the duty to make education available embodies the obligation to make financial and technical provision for an education of good quality. ${ }^{103}$ The UN Committee on Economic, Social and Cultural Rights (CESCR) explains that the kind of facilities the state has to ensure for the good functioning of its educational system depends upon the developmental context within that state. ${ }^{104}$ Paragraph 6 of CESCR's Comment outlines the 'indispensable' facilities required of all institutions regardless of their development status, including the requirement of 'buildings ... sanitation facilities for both sexes, safe drinking water, trained teachers receiving domestically competitive salaries, [and] teaching materials'. ${ }^{105}$ Beyond these basic stipulations, CESCR recognises that the extent to which the obligation to make education available is fulfilled can only be answered on a case-bycase basis. ${ }^{106}$ More advanced facilities, such as libraries and computers, are only considered feasible in developed countries. ${ }^{107}$ This is relevant because the developmental status of Northern Ireland is considerably more advanced than that of 'third world' countries, yet the quality of EOTAS facilities across Northern Ireland is far from uniform and varies greatly, with some centres falling short of the basic requirements.

Tomaševski argues that, in order for governments to meet the 'availability' obligation, functioning educational institutions and programmes must be available in sufficient numbers. ${ }^{108}$ However, being able to provide a sufficient quantity of EOTAS services depends on, among other elements, the ability to identify, calculate and understand the level of need amongst the student body. This is of particular importance because in Ali

97 Colin Harvey, 'Protecting the Marginalised' in John Morison, Kieran McEvoy and Gordon Anthony (eds), Judges, Transition and Human Rights (OUP 2008) 216.

98 This seems to be at least implied by CESCR, General Comment No 13 (n 10) para 6(a).

99 Fons Coomans, 'Clarifying the Core Elements of the Right to Education' (1995) 2: <www.uu.ni/ faculty/leg/nl/organisatie/departmenten/departmentrechtsgeleerdheid/organisatie/onderdelen/ studieeniformatiecentrummensenrechten/publicaties/simspecials/18/Documents/18-03.pdf >.

100 Coomans (n 66) 241.

101 The focus of this analysis is on secondary-level education, specifically alternative education at secondary level, rather than that at pre-, primary or higher education level.

102 Coomans (n 99).

103 Verheyde (n 72) 15.

104 CESCR, General Comment No 13 (n 10) para 6(a).

105 Ibid.

106 Ibid.

107 Ibid.

108 Tomaševski (n 93) 17-18. 
$v$ United Kingdom the ECtHR ruled that the compliance of exclusion decisions with the right to education depends in part upon the sensible efforts of states to provide alternative educational support. ${ }^{109}$ Current methods of identifying pupils in need and the associated ability of the state to plan and provide sufficient EOTAS services has attracted controversy in Northern Ireland. In 2010, the ETI noted that, whilst schools have improved at maintaining engagement with hard to reach pupils, 'the nature of behavioural difficulties experienced by a minority of pupils [was] becoming more complex'110 and there were some pupils identified as at 'risk of marginalisation' with 'very complex needs which are not addressed by the current model of provision'. ${ }^{111}$ Among other issues, the ETI attributed difficulties in quantifying the problem to the lack of an effective data system to record changes in pupil well-being. ${ }^{112}$

At present, individuals formally excluded from mainstream, namely those placed in EOTAS settings among others, are not included in the Summary of Annual Examination Results (SAER) used to measure attainment levels in Northern Ireland. ${ }^{113}$ Each year, principals have the option of omitting students from SAER statistics if they meet DENI specified criteria, which deem them 'ineligible' for inclusion. ${ }^{114}$ In recent years, the trend towards invoking this option has markedly increased, with roughly 5,000 pupils between the academic years 2011/2012 and 2013/2014 being excluded from SAER. ${ }^{115}$ If such pupils had been factored into the overall year 12 cohort reaching five GCSEs $A^{*}-\mathrm{C}$ grades in 2013/14, there would have been a significant decrease in the recorded success rate: 65.2 per cent of all pupils would have fallen to 61 per cent. This hiding of statistics gives the impression that the level of need is much lower than is the case, indicating that EOTAS services could potentially be in higher demand than is currently known. This is concerning, given that such figures set the baseline for yearly publicised school league tables, are quoted in attainment research and are used to allocate DENI funding to schools where need is deemed 'high'. ${ }^{116}$ Although schools are required to collate statistics separately on pupils suspended and expelled, it appears that other cohorts of young people specified within the 'ineligibility criteria' may be equally marginalised from the mainstream system but do not meet the attention of required service providers and are not therefore considered for alternative placement. ${ }^{117}$

Further weight is added to such concerns once the obligation under Article 28(1)(e) of the UNCRC to 'take measures to encourage regular attendance at schools and the

109 Ali v United Kingdom (2011) 53 EHRR 12, judgment of 11 January 2001, para 60.

110 'Report of an Evaluation of Pupil Behaviour in Schools and Other Educational Settings' (n 48) para 4.2.

111 Ibid para 4.3 .

112 Ibid.

113 The 'ineligibility criteria' set out eight categories of young people who may be deemed 'ineligible'. This is published yearly in a DENI Statistical Bulletin detailing Year 12 and Year 14 Examination Performance at Post-Primary Schools in Northern Ireland. The most recent edition is available at: <www.deni.gov.uk/sites/default/files/publications/de/sb-9-2015-year-12-and-Year-14-examination-postprimary-schools-in-northern-ireland-2014-15.pdf $>$ where the criteria are specified on page 6.

114 Ibid.

115 Chris Donnelly, 'The Invisible Pupils: 1 in 10 non-Grammar Kids Excluded from Key Stats' (10 February 2015) <http://sluggerotoole.com/2015/02/10/the-invisible-pupils-1-in-10-non-grammar-kids-excludedfrom-key-stats $>$.

116 Ibid.

117 Those who may be deemed ineligible for inclusion are those whose needs appear greatest, with the criteria permitting omission of those who have a serious illness (which include mental illness and pregnancy), pupils with a statement of special educational needs, those placed in a special unit, as well as those with serious welfare issues. 
reduction of drop out rates'118 is taken into consideration. In 2014, the Northern Ireland Audit Office (NIAO) published a report on 'Improving Pupil Attendance'. ${ }^{119}$ The report aired concerns about the procedural safeguards for detecting and minimising early school drop-outs. It found that, whilst schools had become marginally better at increasing attendance and reducing absenteeism, ${ }^{120}$ in 2011-2012 there remained more than 7,000 primary school pupils and almost 13,000 post-primary school pupils in compulsory education who exceeded the 15 per cent absence threshold and met the criteria for referral to Education Welfare Services (EWS). ${ }^{121}$ Of that number, only 3,881 pupils were referred, which means that approximately 16,000 children missed six weeks of school or more but were neither referred to nor in receipt of the necessary support from EWS.

Some may argue that procedural safeguards within the school environment can prevent this from happening, namely if teachers responsible for the monitoring of attendance and identification of needs were to be required to refer their pupils to the necessary service to gain support. However, the NIAO report found that, with regards to EWS, the 'demand for the service exceeds the resource available and this has put pressure on the EWS'. ${ }^{122}$ As a result, the Chief Education Welfare Officers stated that schools were being actively discouraged from referring all cases and encouraged to refer high priority cases only. ${ }^{123}$ The report highlights that 'there is a risk that, if schools are not proactive in managing these cases, these pupils could slip through the nets'. ${ }^{24}$ This, coupled with the exemption clause provided by the ineligibility criteria, suggests the potential for pupils to pass through the system largely unaccounted for, excluded from attainment statistics and undetected by statutory service providers.

Lundy and Byrne explain that 'data collection is a crucial tool in monitoring national implementation of the CRC', 125 as the 'determination of the state of play at any given point in time, how well a policy is working, its actual impact on targeted group(s) and identification of policy gaps underpins the need for good quality data systems'. ${ }^{26}$ Gaps identified in current accountability mechanisms suggest that the 'availability obligation' has to some extent been negated by the state for young people in need. It would be unjust to say that all pupils who are omitted from SAER statistics alongside the 16,000 highlighted in the NIAO report are in need of EOTAS. Yet it is reasonable to aver that such findings are illustrative of the systemic risks vulnerable pupils face, where it is possible for their needs to go undetected and unaddressed which, in turn, may mean they are not considered for alternative placement. Whilst it is not suggested that EOTAS is a panacea for young people experiencing problems in mainstream schooling, such services can be an effective part of a solution for some of the most vulnerable and disengaged students requiring interventionist provision.

In recent years the term 'alternative education' has gained international popularity. ${ }^{127}$ It is regularly invoked to describe the educational destination of all young people outside of the mainstream system and in some instances is even used to denote young people who

118 UNCRC, Article 28(1)(e).

119 'Improving Pupil Attendance: Follow-Up Report' (NIAO 2014).

120 Ibid 5.

121 Ibid 7.

122 Ibid 39.

123 Ibid.

124 Ibid.

125 Byrne and Lundy (n 32) 271.

126 Ibid.

127 Thomson and Pennacchia (n 19). 
are 'educationally inactive' in that they have left their mainstream school prematurely before compulsory school-leaving age yet have not been provided with an alternative education placement. ${ }^{128}$ Definitional issues surrounding the sector have been complicated by the massive growth and expansion of services that offer an educational alternative to mainstream schools. ${ }^{129}$ Currently, in Northern Ireland, there are differing forms of educational alternatives that vary in quality, outcomes, long/short-term objectives and availability. This is also complicated by access issues, where access to EOTAS services remains segregated and determined by the location of each pupil in need. As mentioned previously, DENI released guidance in 2014 establishing the minimum standards and common features for all alternative provision in what has been termed the EOTAS sector'. This was completed in line with the structural standardisation and amalgamation processes underway in relation to the Education Authority.

Whilst the guidance attempted to inject definitional parameters on EOTAS services across the North, anomalies exist. The guidance has broken down provision into three types: (i) those which are short-term placements with continued school attendance focusing solely on addressing social emotional and behavioural difficulties (SEBD); (ii) those which are longer-term and mostly permanent placements retaining links with school but where the EOTAS setting takes responsibility for delivering the curriculum as well as addressing SEBD; and (iii) exceptional arrangements for young people whose difficulties are so severe that attendance at group provision is temporarily unsustainable. ${ }^{130}$ Within type (ii) a unique type of community-based provision exists for those at Key Stage 4, but it is only available to those in the Greater Belfast area with the exception of one other centre in the legacy South Eastern ELB area. Further to this, the guidance does not extend to EOTAS provision required by reason of physical illness, which the guidance claims uses different referral and assessment processes ${ }^{131}$ and requires different support mechanisms for which guidance has not yet been published. Direction on the use of home tuition as well as 'elective home education' has also been omitted from the guidance, meaning that it is unclear whether or not such provision is considered by DENI to be part of the EOTAS sector. This is known to cause confusion as home tuition is used when no appropriate EOTAS service is available to meet the needs of pupils outside the system. Likewise, in some areas there is no full-time provision for pupils who require longer-term, mostly permanent, placements. ${ }^{132}$ As a result, serious questions arise regarding the provision made for the pupils mentioned above and their compatibility with the right to education.

\section{Accessibility}

It is clearly consistent with the notion of a right to education that a person has to be able to access an institution that provides it. ${ }^{133}$ However, the ECHR does not lay down any specific obligations concerning the extent to which education should be organised or

128 Ibid.

129 Kilpatrick et al (n 25) above.

130 'Guidance on Education Other Than at School' (n 50) para 4.3. Commonly in Northern Ireland this includes young people who are incarcerated or detained in a secure facility as well as those who are placed in secure care.

131 Ibid para 1.2, fn 1.

132 'Education Other Than at School and Youth Work' (Northern Ireland Assembly Briefing Paper 26/15, NIAR 905-14, January 2015). Pages 10-12 detail provisions available in each legacy ELB area.

133 Tomaševski (n 93) 13. 
subsidised in each state. The extent of A2P1 in this respect was interpreted in the Belgian Linguistics case. ${ }^{134}$ Here the ECtHR found that in the operative sense A2P1 does not require state parties to establish a particular education system but, instead, held that the first sentence of A2P1 would be meaningless if it did not imply, in favour of its beneficiaries, the right of access to an educational institution existing at a given time. ${ }^{135}$ Furthermore, the ICESCR states that education should be accessible to everyone, especially the most vulnerable groups in law and fact, and without discrimination on any of the prohibited grounds. ${ }^{136}$ This requires states to 'closely monitor all education including relevant policies, institutions, programmes spending patterns and other measures, so as to identify and take measures to redress any de facto discrimination'. ${ }^{137}$ CESCR further comments that data should be disaggregated by the prohibited grounds of discrimination and that education should be physically accessible and affordable to all. ${ }^{138}$ While this may be the case for pupils attending mainstream schools, children and young people who are excluded are not afforded equality of access to education in Northern Ireland. Aside from the disparities mentioned above in relation to differential types of provision available in legacy ELB areas, there are a number of access inequalities inherent in the process of identification, referral and consideration for EOTAS services too.

Domestically, the notion of an 'accessibility' obligation in EOTAS settings stems from article 86(1) of the Education (NI) Order 1998 which states that ELBs, and now the Education Authority, 'shall make arrangements for the provision of suitable education' for those outside of the mainstream system. This was reaffirmed in the EOTAS guidance, which states that in making a decision to allocate an alternative placement:

. . . only an ELB can determine that a pupil requires an EOTAS placement.

Schools, EOTAS providers or the parents/guardians of a pupil may not bypass their ELB's referral and decision making process. ${ }^{139}$

When ELBs were still in existence, this provision could be viewed in a positive light as it allowed for flexibility in determining how each ELB designed and implemented its services to meet the individual needs of students. However, this posed problems with regards to equity of access. Whilst the guidance states that ELBs are the only organisations that may determine placement, it 'does not attempt to set out detailed processes and procedures for all aspects of EOTAS provision'. ${ }^{140}$ Currently, there are five different referral criteria in operation across each of the legacy ELB areas. Despite the creation of one Education Authority, as well as a review of the implementation of the EOTAS guidance fast approaching in 2017, DENI has not yet published operational policy establishing a clear, transparent and systematic common referral process. It is in this transitionary period that questions relating to the operationalisation of the Education Authority's aim to ensure 'that every pupil ... in Northern Ireland will have access to the same services, no matter

134 Belgian Linguistics Case (No 2) (1968) 1 EHRR 252.

135 Ibid para 4.

136 The grounds include: race, colour, sex, language, religion, political or other opinion, national or social origin, property or other status. See ICESCR 1966, Article 2. The UNCRC also includes disability as a ground for non-discrimination.

137 Lundy et al (n 4) 7.

138 CESCR, General Comment No 13: The Right to Education (Article 13 of the Covenant), 8 December 1999 , E/C12/1999/10, para 37.

139 'Guidance on Education Other Than at School' (n 50) para 4.10.

140 Ibid para 1.3. 
which school they are in, what community they come from, or where they are geographically'141 are most pertinent. The Education Authority claimed the outcome of the amalgamation of ELBs would mean that a 'child with special educational needs in Omagh will receive the same treatment as a child in similar circumstances in Armagh, Belfast, Downpatrick or Ballymena'. ${ }^{142}$ This is not the case at present for young people outside of the mainstream system. In terms of accountability, the EOTAS guidance has set the benchmark of how a common referral process should work, with the potential to provide more adequate means of quantifying and standardising referral operations across the North. However, more procedural clarity is required.

In Ali $v$ United Kingdom ${ }^{143}$ the ECtHR provided important guidance on the circumstances in which school exclusion will be deemed incompatible with A2P1 rights. As well as the adequacy of alternative education provided, a number of other factors have to be considered, such as the extent of applicable safeguards, the duration of exclusion, the extent of the applicant's cooperation with any reintegration efforts, steps taken to minimise the effects of exclusion, and the extent to which the rights of third parties are engaged. ${ }^{144}$

This ruling is a welcome development and one that may provide encouragement for potential claimants in Northern Ireland whose educational entitlements have not been met in the EOTAS setting. The judgment signifies that the Strasbourg court is willing to take a multi-factorial approach towards future cases, where a strong set of facts on the use of exclusions believed to be incompatible with A2P1 could result in a successful claim. That being said, the court did not demonstrate any willingness to extend protection to the growing number of young people placed on temporary exclusions in certain respects. The court accepted that $\mathrm{A} 2 \mathrm{P} 1$ does not require students who are temporarily excluded to have access to the entirety of the national curriculum. This is concerning, as there has been a substantial increase in the use of suspensions in Northern Ireland. ${ }^{145}$ In addition to the absence of affirmative action from the Education Authority or DENI, the domestic judiciary appear to be unwilling to intervene in this area of policy. This is evidenced by the procedural impropriety that occurred in an unlawful suspension case taken by an anonymised applicant for judicial review known only as JR17.146 Here, despite the judges deeming the suspension that was implemented to be unlawful, no breach to the right to education was declared. Sir John Dyson was unwilling to depart from Lord Bingham's analysis of the right to education in the House of Lords decision in $A l i{ }^{147}$ as though it were written on tablets of stone that a school suspension could not amount to a breach of A2P1 even where inadequate provision had been made through home tuition. Conceptually, Lord Bingham's view does not go far enough to protect the right to access education for young people excluded from school. His view is that A2P1:

... [i]n comparison with most other Convention guarantees, is a weak one and deliberately so. There is no right to education of a particular kind or quality, other

141 Better Government for Northern Ireland: Final Decisions of the Review of Public Administration (Northern Ireland Office 2006) 12, available at <http://cain.ulst.ac.uk/issues/policy/publicadmin/rpani210306.pdf>.

142 Ibid.

143 Ali v United Kingdom (n 109).

144 Ibid paras 55-67.

145 In the academic year 2014/15 9,198 suspensions were imposed on 3,647 pupils in Northern Ireland. The majority of these were experienced by white males, 1,171 of whom were suspended more than once; see: 'Pupil Suspensions and Expulsion - 2014/15 statistics' (DENI, 12 November 2015) <www.deni.gov.uk/ sites/default/files/publications/de/pupil-suspensions-2014-15.pdf>.

146 Re JR17's Application [2010] UKSC 27, [2010] NI 105.

147 Ali v Head Teacher and Governors of Lord Grey School [2006] UKHL 14, [2006] 2 AC 363. 
than that prevailing in the state. There is no Convention guarantee of compliance with domestic law. There is no Convention objection to the expulsion of a pupil from an educational institution on disciplinary grounds, unless (in the ordinary way) there is no alternative source of state education open to the pupil ... The test as always under the Convention is a highly pragmatic one, to be applied to the specific facts of the case: have the authorities of the State acted so as to deny to a pupil effective access to such educational facilities as the State provides for such pupils? ${ }^{148}$

When a pupil is temporarily excluded from school he or she remains excluded from full access to the curriculum, his or her involvement in the social aspects of school is terminated and the young person is placed at an increased likelihood of disenfranchisement from the education system. For these reasons, the judgment in Aliv United Kingdom, when read in conjunction with data demonstrating excessive use of temporary exclusions in Northern Ireland, is of serious concern.

Duncan and McCrystal warn that there is growing evidence on the use of informal suspensions' that often go unrecorded and 'remain largely hidden and . . . absent from official statistics'. ${ }^{149}$ Such sanctions are often framed as child- and parent-friendly in nature, ${ }^{150}$ however, it is possible that in such instances a pupil's right to education may be compromised. This is because they are in effect denied education in their original school environment and, in addition, avoid procedural safety nets established by the government. This is so because it is unlikely that pupils in these circumstances will be referred to the requisite statutory service provider, who will not therefore assess whether an alternative placement outside the mainstream system would be appropriate. The practice of internal exclusion'151 was not raised before the ECtHR in Ali. This is regrettable because such practices are equally as disciplinary as formal exclusion processes, but with heavier exclusionary consequences given that the duty to support the pupil to access and secure another mainstream placement is passed on to parents once the child is 'voluntarily removed' from the system. It is possible that this could result in reduced opportunities to avail of statutory and therapeutic support services that would be readily available should a pupil go through the official route of formal exclusion.

Due to their unofficial/unrecorded status, such actions go unchallenged, unquantified and unaddressed. ${ }^{152}$ Lack of oversight by the judiciary alongside the procedural loopholes evident in the system exonerate schools from fulfilling their statutory duties to act in the best interests of the child and exhaust all plausible avenues of support to continue the mainstream placement. Practices such as this may account for the difficulties inherent in identifying and tracing some children who prematurely exit their mainstream placements and are now 'lost to the system', i.e. have not been registered at school or have

148 Ali v Head Teacher and Governors of Lord Grey School [2006] UKHL 14, [2006] 2 AC 363, para 24, quoted in Re JR17's Application [2010] UKSC 27, [2010] NI 105, para 59.

149 Duncan and McCrystal (n 22) 177.

150 Ibid.

151 During an internal exclusion pupils remain on school premises yet are prohibited from joining their peers for routine school activities. This could constitute spending a period of time outside of the classroom with or without work, in a corridor or in withdrawal rooms, where they go to 'cool down'. See Evans (n 19) 24. Within Northern Ireland this procedure is better known as 'isolation' and is a common form of punishment for disruptive children which requires them to take 'time out'. This has led educational experts and campaigners to conclude that there 'is a quiet scandal in the education system with a growing number of children being illegally denied an education through unofficial exclusions and local authority failings'. See Lundy (n 30) 218.

152 Macrae et al (n 27). 
left a school and no one knows where they are. ${ }^{153}$ It remains impossible to assess the extent of this problem as data on the use of internal exclusion remains uncollated in Northern Ireland. The Northern Ireland Commissioner for Children and Young People (NICCY) agrees that procedures in place for dealing with suspensions and expulsions are inadequate, ${ }^{154}$ highlighting that suspensions are in many ways worse because there is no appeal mechanism in place to challenge a decision of this sort. ${ }^{155}$ Due to the high use of suspensions consistently invoked across Northern Ireland, as well as the finding that some pupils are suspended more than once, ${ }^{156}$ it is questionable whether such sanctions are truly imposed as a last resort ${ }^{157}$ - which is the standard stipulated by UNCRC. ${ }^{158}$

In the absence of a more proactive response from the judiciary on the use of temporary exclusion, relying on a broader conception of the right to education, it is unlikely that the access inequities stemming from the use of informal/in-house exclusions' will be rectified soon. This serves as a reminder that protecting the educational entitlements of those excluded from school is unlikely to be solvable via a one-dimensional approach to the issue. Whilst the overarching aim of maintaining pupils in mainstream schools remains, it is difficult to envisage its realisation unless a more effective and coordinated system of accountability is developed, in line with international standards, which increases the capability of the authorities to identify potential risk factors contributing to early school leaving. In tandem, sufficient reporting and recording mechanisms on the destination of early school-leavers are necessary in order to ensure that all young people regardless of their needs or prior school experience are afforded their right to education. The Northern Ireland Executive should be implored to take on this mantle.

\section{Acceptability}

The notion of an 'acceptability' obligation in EOTAS stems from article 86(1) of the Education (NI) Order 1998. This states that each ELB, now the Education Authority, 'shall make arrangements for the provision of suitable education', that is 'efficient education suitable to [the] age, ability and aptitude and to any special educational needs a pupil may have'. Corresponding EOTAS guidance states that the key goal of alternative education is to meet the learning needs of pupils who are unable to access their education in a mainstream setting. ${ }^{159}$ It further states that the focus of EOTAS must be on helping children and young people to address and overcome the social, emotional and behavioural difficulties or other barriers which are preventing them from accessing learning whilst ensuring educational progression. This follows from the fact that such pupils remain entitled to access a broad education, which reflects their individual needs and abilities. ${ }^{160}$ Thus, the extent to which education is deemed 'acceptable' or 'suitable' for excluded young people is synonymous with the notion of quality. Both the CESCR and the UN

153 'Improving Pupil Attendance: Follow-Up Report' (n 119) 39.

154 'Children's Rights: Rhetoric or Reality' (n 71) 287.

155 Re Robert McMillen's Application [2008] NIQB 21.

156 For example, in 2016 a high school made local headlines for sanctioning 87 more suspensions than the total number of students attending, in other words 440 suspensions out of 353 students. See, 'Movilla High School Suspended Pupils 440 Times in One Year' BBC News (27 January 2016) <www.bbc.co.uk/news/uk-northernireland-35417136>.

157 Roughly 10,000 suspensions were implemented in 2014/2015. Statistics on the level of suspensions implemented in Northern Ireland since 2001/2002 are available on DENI website <www.deni.gov.uk/ publications/pupil-suspensions-and-expulsion-statistics-201415>.

158 'Children's Rights: Rhetoric or Reality' (n 71) 288.

159 'Guidance on Education Other Than at School' (n 50) para 3.1.

160 Ibid para 4.2. 
Committee on the Rights of the Child concur and have made it clear that education has to be effective and of good quality. ${ }^{161}$ In this regard, the CESCR has explicitly stated that the form and substance of education, including curricula and teaching methods, must be 'acceptable'. 162

Yet the definition of 'suitable' or 'acceptable' education remains disputed in both domestic and international courts. ${ }^{163}$ As aforementioned, the negative phraseology of the first sentence of $\mathrm{A} 2 \mathrm{P} 1$ is such that the intended guarantee of access to education is not made parallel with the required quality of education. However, the right to an 'effective education' was affirmed in the Belgian Linguistics case ${ }^{164}$ to some extent, where the parameters of the right to education were expanded by requiring that for A2P1 to be meaningful the quality of education must meet a minimum standard in educational institutions as they exist. ${ }^{165}$ This means that a beneficiary of the system must be able to draw profit from their education and, in conformity with the rules in force in each state, obtain official recognition of studies that have been successfully completed. ${ }^{166}$ This finding was affirmed in Leyla Sabin v Turkey, ${ }^{167}$ where the Grand Chamber of the ECtHR explained that access to education constitutes only part of the right because for A2P1 to be effective 'it is further necessary, inter alia, that the individual who is the beneficiary should have the possibility of drawing profit from the education received'. ${ }^{168}$

Nonetheless, A2P1 cannot be said to guarantee to children out of mainstream school the right to receive education in EOTAS settings to an equal extent to that in their original school. The House of Lords decision in Ali discussed above established that, even where a failure to satisfy educational requirements in domestic law occurs, it will not necessarily constitute an infringement of A2P1. ${ }^{169}$ Ali was later upheld in $A v$ Essex County Council, ${ }^{170}$ where failure to provide education for 18 months to a child with special educational needs in line with domestic legislation did not amount to an infringement of A2P1, as resources were not immediately available to carry out a necessary assessment nor thereafter for a placement that would satisfy the applicant's needs. Here, the judiciary affirmed that there is a minimum standard that must be met relative to what exists in each state, ${ }^{171}$ but insisted once again that the right only extends as far as the educational provision that exists in state parties at a given time. ${ }^{172}$ This means, for instance, that, if facilities are limited so that immediate access cannot be granted instantly, A2P1 must have regard to that limitation. ${ }^{173}$ The obvious query which arises here centres on the standards pertaining in each state and the regulation of such therein.

161 CESCR, General Comment No 13 (n 10) para 6(c); Committee on the Rights of the Child, General Comment No 14, The Right of the Child to Have his or her Best Interests Taken as a Primary Consideration (Article 3(1) of the Convention), CRC/C/GC14, 29 May 2013, para 79.

162 Ibid.

163 Oreste Pollicino, 'The New Relationship between National and the European Courts after the Enlargement of Europe: Towards a Unitary Theory of Jurisprudential Supranational Law?' (2010) 29 Yearbook of European Law 65.

164 Belgian Linguistics Case (No 2) (1968) 1 EHRR 252.

165 Ibid para 3.

166 Ibid para 4.

167 Leyla Şabin v Turkey (2005) 44 EHRR 99.

168 Ibid para 154.

169 Ali v Head Teacher and Governor of Lord Grey School [2006] UKHL 14, [2006] 2 AC 363.

170 A v Essex CC [2010] UKSC 33, [2011] 1 AC 280.

171 Ibid [19].

172 Belgian Linguistics Case (No 2) (1968) 1 EHRR 252, para 3 (emphasis added).

173 Ibid para 86. 
If, for example, a young person living in a legacy ELB area in Northern Ireland is excluded from school yet requires a level of education that is longer-term and full-time in nature, he or she will not receive such provision if none currently exists in that area. However, should the same young person reside in another legacy ELB area, he or she could potentially be offered a number of full-time alternative provisions. The extent of this issue is indeterminate. In theory, due to the creation of a singular Education Authority governing education across the North, access should be made possible irrespective of postcode. Yet it is unclear what outcome would occur in practice, hence the need for clarification and prompt operational policy from DENI. In light of Av Essex County Council, it appears to follow that decisions on the suitability or effectiveness of the content of EOTAS centre on the availability of resources existing when an alleged infringement of educational rights occurs.

The leading ECtHR judgment on such arguments is again Aliv United Kingdom. ${ }^{174}$ Despite the fact that alternative education provision made for the appellant in this case was of lower quality than that in mainstream placement, the court was unsympathetic because he and his parents did not cooperate with the authorities and refused to avail of the alternative placement in question. The court held that 'had he taken up the offer of education at the PRU [Pupil Referral Unit] and brought judicial review proceedings, the relevant question for the Court would have been whether the education provided at the PRU was suitable'. ${ }^{175}$ This decision represents a departure from previous case law in that it suggests the content of the right which A2P1 protects may be held to the domestic legal standard existing in the state party rather than some lower objective minimum standard. Thus, in theory, it would seem that a pupil may be able to pursue a case if educational provision to which he or she is legally entitled under domestic law is not available and accessible, representing a progressive step towards the full realisation of the right to education by the ECtHR.

It is impractical to suggest that effective access to educational facilities which exist within the state amounts to fulfilling educational rights if facilities themselves are of poor or insufficient quality and do little to develop the young person as a recipient. Additionally, it is questionable how effectively a full curriculum may be covered within limited teaching hours. This is especially so where pupils have contended with increased adversities commensurate with the exclusions process and are more often than not lagging behind their mainstream peers and therefore required to play educational catchup in the pursuit of completing academic courses to gain meaningful accreditation. It would follow that the allocated time for delivery of the curriculum would necessitate fulltime provision. If this were not the case, mainstream schools would operate on the same basis of four hours taught provision per week, yet they do not. The UN Committee on the Rights of the Child notes that efforts to promote the enjoyment of child rights must not be undermined, and should be reinforced by the values imparted in the educational process. ${ }^{176}$ It is argued that providing a child with a lower standard of education via reduced hours of home tuition, which occurred in JR17, ${ }^{177}$ injures the substance of the right to education and conflicts with the very essence of the ECHR and other rights contained therein. The implications of Ali somewhat ameliorate contradictory messages from previous Strasbourg case law which indicated that the acceptability of educational

174 Ali v United Kingdom (n 109).

175 Ibid para 31.

176 Committee on the Rights of the Child, General Comment No 1 (n 9) para 8.

177 Re JR17's Application [2010] UKSC 27. 
provision is not relevant, applicable or guaranteed to those who find themselves outside the mainstream system.

NICCY argues that the fact young people cannot avail of the same opportunities as their peers in mainstream represents a 'clear contradiction with a non-discriminatory rights-based approach to education provision'. ${ }^{178}$ Given the vulnerability of EOTAS recipients and the complexity of needs they present with, it is imperative that support, finance and resources are invested in alternative settings. Alongside NICCY, the ETI has been critical of the educational content within some EOTAS settings, where it feels pupils are not reaching their full potential and that the curricula opportunities available are more restricted than those available in mainstream educational settings. ${ }^{179}$ The Chief Inspector, in her most recent report, noted that 71 per cent of EOTAS centres inspected were good, indicating that the remaining 29 per cent of provisions were less effective, where the quality of teaching was weaker, coupled with reduced opportunities for vocational training and career pathways, meaning young people may be at an increased risk of further exclusion. ${ }^{180}$ Amongst other issues, those considered 'less effective' had poor rates of attendance. Kilpatrick et al also draw attention to the inequities in alternative settings, not least the provision of inadequate funding, which they say characterises the 'ad hoc nature and inequalities associated with the system'. ${ }^{181}$ It is imperative that further action is taken to remedy such inequalities.

\section{Adaptability}

The CESCR has stated that in order for education to be effective it must be flexible so that it can adapt to the needs of changing societies and communities and remain able to respond to the needs of students within their diverse social and cultural settings. To this extent, education must be adaptable. ${ }^{182}$ In light of the issues discussed above in relation to constrained resources and the reduced ability of EOTAS services to meet the requirements of acceptable education provision, it is clearly debatable how adaptable staff within some EOTAS settings can be. It is suggested that staff may be preoccupied with ensuring that they meet the minimum requirements of the EOTAS guidance, given that they are operating in an environment with uncertain funding and minimal resourcing which results in efforts directed towards simply keeping centres open. ${ }^{183}$ The absence of guaranteed funding places pupils at a disadvantage, as leadership and management are unable to forward-plan to deliver effective services, ${ }^{184}$ whilst staff have to contend with

178 'Children's Rights: Rhetoric or Reality' (n 71) 289

179 'Chief Inspector's Report' (2012) (n 18) 70, para 203.

180 'Chief Inspector's Report' (2014) (n 18) 68.

181 Kilpatrick et al (n 25) 127.

182 CESCR, General Comment No 13 (n 10), para 37; UN Committee on the Rights of the Child, Concluding Observations: United Kingdom of Great Britain and Northern Ireland, 20 October 2008, CRC/C/GBR/CO/4, para 67.

183 Len Barton and Felicity Armstrong, 'Policy Experience and Change: Cross-Cultural Reflections on Inclusive Education' (2008) 4 Inclusive Education 1.

184 'Report of a Follow up Inspection: The Pathways Project' (ETI 2012); 'Report of an Inspection: Upper Andersonstown Community Forum, Youth Education and Training Forum' (ETI 2009); 'Report of an Inspection: Education by Choice Centre, The Bridge Community Association' (ETI 2007). All of these reports make reference to lack of planning and strategic leadership. 
the prospect of job uncertainty in the context of delivering an already emotionally and physically demanding service. ${ }^{185}$

Kilpatrick et al noted that 'successful AEP'186 often relies on the efforts of highly motivated and committed individuals, but it seems that there is little except personal satisfaction for them in terms of reward'. ${ }^{187}$ If staff are already working at full capacity in the pursuit of continued EOTAS service delivery, it is unlikely that they are capable of adapting services in an environment that does not lend time, resources, research nor investment. It is unreasonable to expect EOTAS staff to sustain efficient development of current models when a reserve of professional knowledge in the field is hampered through a lack of access to in-service training days provided by legacy ELBs. ${ }^{188}$ To reiterate the point, inadequate and insecure funding impacts on the development of EOTAS provision in various negative ways, not least the adaptability of the service. ${ }^{189}$

Despite this, attention has consistently been drawn to the strong positive working relationships developed between staff and young people in EOTAS settings. ${ }^{190}$ Likewise, there is evidence to suggest that some EOTAS services, within the community sector, for example, are working innovatively to ensure that a human-rights based approach to EOTAS delivery is to some extent being implemented. Within the Belfast area, a Youth Forum has been established between community-based providers whereby previous and current students take part in capacity-building exercises to enable them to advocate on behalf of their peers as well as contribute to quality assurance and decision-making within the centres. Although this does not signify full implementation of children's and young people's participatory and educational rights in EOTAS services, it acts as a starting point. ${ }^{191}$

Much more needs to be done to ensure that the voice of the child is given due weight and consideration from the point of any initial proceedings involving the identification and assessment of young people, through to the allocation of alternative education placements where children's views appear to be largely omitted. This is evidenced by large numbers of pupils in EOTAS who demonstrate a 'worrying lack of understanding . . . as to why they have been placed in AEP'. ${ }^{192}$ This reflects the UN Committee on the Rights of the Child's wider concern that 'school children are not systematically consulted in matters that affect them'. 193 On this matter, Foucault ${ }^{194}$ argues that:

... [i]f the protests of children were heard in kindergarten, if their questions were attended to, it would be enough to explode the entire educational system.

185 For a detailed discussion on the 'emotional labour' of staff working in alternative provisions, see Martin Mills and Glenda McGregor, Re-Engaging Young People in Education: Learning from Alternative Schools (Routledge 2014).

186 There are many different names given to educational provision made for children outside of the mainstream schooling system. In this instance AEP is used as an umbrella term to denote all types of alternative education provision.

187 Kilpatrick et al (n 25) 127.

188 Ibid.

189 Bryson (n 17) 353.

190 'Report of an Evaluation of Pupil Behaviour in Schools and Other Educational Settings' (n 48) 4, para 5.3.

191 Extern Northern Ireland and Extern Group, 'Annual Report 2014-2015': <www.extern.org/sites/default/ files/documents/extern_ni_and_group_ar_2015.pdf $>$.

192 Coomans (n 66) 288.

193 UN Committee on the Rights of the Child, Concluding Observations: United Kingdom of Great Britain and Northern Ireland, 9 October 2002, CRC/C/15/Add 188.

194 Michel Foucault, 'Intellectuals and Power: A Conversation between Michael Foucault and Gilles Deleuze' in Donald Bouchard (ed), Language Counter-Memory, Practice: Selected Essays and Interviews (Cornell UP 1977) 205-07. 
Not only are prisoners treated like children, children are treated like prisoners. Children are submitted to an infantilization that is alien to them. ${ }^{195}$

Whilst the limits of this article do not extend far enough to engage in a full discussion of how children's participatory rights may offer a solution to the inequities inherent in the EOTAS sector, one cannot help but wonder, if the protests of disadvantaged, schooldistant, marginalised or disruptive pupils were truly given a platform to be authentically heard, interpreted and addressed, would the need for EOTAS services remain as is or could more pupils be maintained in mainstream? Would the system simply explode?

\section{Conclusion}

In its Concluding Observations in 2008 on UK practices, the UN Committee on the Rights of the Child highlighted that, whilst the state should provide an effective education for all, those who are 'disadvantaged, marginalised and school-distant' require the investment of 'considerable additional resources to ensure the right to all children to a truly inclusive education'. ${ }^{196}$ In this regard, DENI states that it is 'axiomatic that all pupils, including those with behavioural problems, remain entitled to a broad and balanced curriculum'. ${ }^{197}$ However, the lack of 'systematic or coherent support from the wider system' has had a definitive impact directly upon services delivered by community as opposed to statutory services. Save the Children has been critical of this lack of support, arguing that 'government cannot cheat by doing it on the cheap, buying into big ideals with little provision to back it. Children needing alternative education challenge providers to higher levels of quality'. ${ }^{198}$

There is evidence of some steps in the right direction towards full realisation of the A2P1 right to education for pupils in, to and through EOTAS. However, the ECtHR's leading decision in $A l i,{ }^{199}$ current domestic legislation, departmental guidance, and inspectorate accountability mechanisms, on their own, are not sufficient to preserve the human dignity innate in every child as their equal and inalienable rights are not fully protected and promoted by the educational rights system. ${ }^{200}$ While it may appear that the guidance has gone some way to establishing a minimum baseline of what is expected of providers, it seems that the context for delivery of 'quality alternative education' remains agitated by the disconnect that exists between governmental aspirations, legislation, policy and EOTAS sector operations. This is further agitated by reduced access to resources alongside the corresponding lack of a consistent operational strategy to deliver the minimum requirements of EOTAS guidance.

In England and Wales, departmental guidance states that the school with which the pupil is last registered is required to make provision within a maximum of 12 days of exclusion. $^{201}$ Stipulations such as this, although not entirely protective, make the allocation of alternative education provision legally compulsory in order to ensure that nothing prevents young people from availing of their educational entitlements. Implementing similar provisions in Northern Ireland, although not a comprehensive

195 Ibid 209-10.

196 UN Committee on the Rights of the Child, 20 October 2008, CRC/C/GBR/CO/4, para 66.

197 'Promoting and Sustaining Good Behaviour' (n 37) para 4.1.

198 'Not Included? A Report of a One Day Conference Exploring Community-Based Alternative Education' (Save the Children 2005) 353.

199 Ali v United Kingdom (n 109).

200 Michael Freeman, 'Why It Remains Important to Take Rights Seriously' (2007) 7 International Journal of Children's Rights 5.

201 Thomson and Russell (n 92) 424. 
solution by any means, would act as an additional procedural safeguard for those negotiating their way through the exclusion and reallocation process so as to ensure as a starting point that barriers to learning for the most marginalised and disadvantaged young people are reduced and adequate provision is put in place within the shortest reasonable timeframe. Article 86 of the Education (NI) Order 1998 required ELBs, now the Education Authority, to make alternative provision for pupils of compulsory school age, yet, should a pupil be referred for consideration of alternative placement half-way through his or her last year of compulsory schooling there is a possibility that he or she could fall outside the statutory remit for reallocation, depending on how often the deciding referral body meets and how quickly an assessment is completed. ${ }^{202}$ This is the same for any pupil under consideration for an EOTAS placement. In the absence of a specified time limit placed on statutory decision-makers to ensure alternative placement is finalised, pupils may experience periods of absence from education. Given the adverse social, developmental and economic costs related to such educational inactivity, this lacuna warrants immediate attention.

202 Information from each ELB on how often decision panels meet varies, with some convening on a weekly basis as opposed to those that meet on a monthly or quarterly cycle. For example, reference is made to time delays and the regularity with which the deciding educational options panel meets for the legacy Belfast ELB area, see: Belfast ELB Education Options Panel Procedural Guidelines for the Provision of Education Otherwise Than at School (June 2012) <www.belb.org.uk/Downloads/cyps_education_options_panel_procedural_ guidelines_review.pdf $>$. 